\title{
SÍMBOLO Y ALEGORÍA O REDENCIÓN Y MELANCOLÍA: ESTÉTICA DEL BARROCO SEGÚN WALTER BENJAMIN*
}

\author{
Marc Berdet \\ Pontificia Universidad Católica de Valparaíso, Facultad \\ de Arquitectura y Urbanismo - Instituto Arte \\ marcberdet@gmx.com
}

\begin{abstract}
RESUMEN / ABSTRACT
Siguiendo su idea de la tarea del crítico, Walter Benjamin hace surgir imágenes de felicidad de Calderón en el paisaje "originario" en ruinas de Gryphius: la estrella fugaz del barroco español brilla, intermitente, en las tinieblas demoníacas del barroco silesio. El barroco no encuentra así su verdad sino en la inversión dialéctica de su melancolía alegórica en el momento simbólico de la redención. Intento demostrar cómo se manifiesta, en Origen del drama barroco alemán, una dialéctica figurativa suspendida entre símbolo y alegoría, melancolía y redención, precursora das "imágenes dialécticas" que van a polarizar las fantasmagorías capitalistas entre alegoría y utopía.

Palabras Clave: Walter Benjamin, alegoría, símbolo, melancolía, redención, barroco, expresionismo, Calderón, Shakespeare, Gryphius, Goethe, romanticismo, tragedia, dialéctica, fenómeno originario.
\end{abstract}

SYMBOL AND ALLEGORY OR REDEMPTION AND MELANCHOLY: AESTHETICS OF THE BAROQUE ACCORDING TO WALTER BENJAMIN

Following his idea of the task of the critique, Walter Benjamin makes appear Calderon's images of happiness into Gryphius' ruined "original" landscape: the fleeting star of Spanish baroque shines intermittently into the demoniac darkness of Silesian baroque. The baroque is thus only able to meet its own truth through the inversion of its allegorical melancholy into the symbolic moment of redemption. I am aiming at demonstrate how, in Origin of German baroque, a figurative dialectic manifests itself, frozen between symbol and allegory, melancholy and redemption, forerunning the "dialectic images" that will polarize capitalist phantasmagorias between allegory and utopia.

KEYWORDS: Walter Benjamin, allegory, symbol, melancholy, redemption, baroque, expressionism, Calderón, Shakespeare, Gryphius, Goethe, romanticism, tragedy, dialectics, original phenomena. 
Ante mí yacen el príncipe y la corona. Camino sobre el cetro y la cruz, sobre el padre y el hijo. Joya, pintura, metal, una obra erudita. Esto no es para mí, más que polvo barrido por el viento. Andreas Gryphius, Catalina de Georgia

Esto es sueño; y pues lo es, soñemos dichas agora, que después serán pesares. Pedro Calderón de la Barca, La vida es sueño

RRA En 1923, Walter Benjamin comenzó a redactar su tesis de habilitación en literatura alemana (necesaria en Alemania para emprender una carrera universitaria) bajo el título Origen del drama barroco alemán (Ursprung des deutschen Trauerspiels). Sin embargo, no se trataba en sentido estricto de un estudio sobre historia de la literatura. Mediante su concepto de origen, Benjamin cree poder revelar la esencia de un género literario. Aun más, tratará por ese medio de acceder a la esencia de toda creación cultural, como hiciera en cierto modo Nietzsche al trabajar sobre el "nacimiento" de la tragedia. En otras palabras, Benjamin quiere mostrar cómo cada género expresa, a su modo, el ideal que sirve de modelo a la producción literaria, un proceso válido tanto para géneros reconocidos como la tragedia y para géneros subvalorados como el drama barroco alemán.

Como señala la dedicatoria, Benjamin proyectó esta investigación en 1916, época en la que escribió dos breves artículos sobre el drama barroco silesio: "Trauerspiel y tragedia" y "La significación del lenguaje en el Trauerspiel y la tragedia". La redacción comienza en Capri en 1924 y finaliza en Berlín en 1925, con la adición de un denso y complejo prefacio: el "Prologo epistemocrítico", que sistematiza una "ciencia del origen" aplicada al género literario. En sus cartas, el postulante califica este tratado epistemológico como una "impertinencia desmesurada" y un "zarzal", erigido contra los lectores y el texto ${ }^{1}$. Desea descoyuntar el "comercio científico idealista-burgués"2 que caracteriza la cultura universitaria, introduciendo su dialéctica del origen en el campo de la germanística. Por prudencia, intenta sin embargo presentarla bajo los parámetros aceptables de una investigación "histórico-filosófica". Pero sus informantes, espantados por este prefacio esotérico y por su aparente desconexión del cuerpo del

1 Carta a Scholem del 19.02.1925. En Walter Benjamin, GesammelteBriefe 1910-1940, vol. III. Francfort: Suhrkamp, 1995-2000, p. 14 (ahora: GB III).

$2 \quad$ Carta a Rychner del 07.03.1931. En GB IV, p. 18. 
texto, que parece un montaje de citas, estiman que su trabajo es incomprensible y rechazan otorgarle la habilitación.

Si bien no calza en absoluto con las normas universitarias de la época, este libro, uno de los tres que Benjamin publicó en vida (con Dirección única y su tesis sobre el romanticismo), es sin embargo crucial para comprender su pensamiento. Abarcando un decenio, viene a concluir un importante ciclo de trabajo ligado a la literatura alemana, al que sucederá un ciclo francés. El año de su concepción es también el año en que escribe "Sobre el lenguaje en general y el lenguaje de los hombres" (1916), texto del que el prefacio constituye una "segunda versión"3. Su escritura sigue de cerca a "Las afinidades electivas de Goethe" (1922), y su método de composición retoma la exégesis inaugurada con "Dos poemas de Friedrich Hölderlin" (1914-1915) y teorizada en El concepto de crítica de arte en el romanticismo alemán (1919). El candidato cita también textos publicados en 1921 sobre la culpa en la tragedia y sobre la dimensión política de la violencia divina, "Destino y carácter" y "Para una crítica de la violencia". Finalmente, el Origen del drama barroco alemán prosigue un trabajo que se inicia con una recensión cruzada entre un dramaturgo alemán del siglo XIX, Christian Friedrich Hebbel (1813-1863) y uno español del siglo XVII, Pedro Calderón de La Barca (16001681), fechada en $1923^{4}$. Las tragicomedias del español católico constituyen incluso el "objeto virtual del tratado", que versa oficialmente sobre las obras tristes de un teatro silesio de inspiración protestante y cuyo efecto en la literatura alemana actual Benjamin se propone evaluar.

\section{La actualidad del drama barroco alemán}

En 1924, durante la redacción de su tesis de habilitación sobre el barroco alemán, Benjamin se encuentra en Capri en compañía de Asja Lacis. Mientras que, tras las revoluciones rusa y alemana, los movimientos de vanguardia no cejan en su intento de intervenir en el campo político, Benjamin pasa sus días escribiendo sobre este teatro silesio nacido en el siglo XVII, que nunca fue puesto en escena y que solo conocían unos pocos especialistas. AsjaLacis, partidaria de un teatro proletario, pone en cuestión su trabajo con ánimo provocador: "¿Por qué ocuparse de una literatura muerta?”. Benjamin le responde que desea fundar una nueva terminología para la ciencia estética: mediante una distinción rigurosa entre Tragödie y Trauerspiel, dará cuenta de la huella

3 Carta a Scholem del 19.02.1925. En GB III, p. 14.

$4 \quad$ "El mayor monstruo, Los celos de Calderón y Herodes y Mariene de Hebbel". En Walter Benjamin, Obras, vol. II.1. Madrid: Abada, 2006, pp. 250-280 (ahora: Obras II.1) [Walter Benjamin, Gesammelte Schriften, vol. II. Frankfort: Suhrkamp, 1972-1999, pp. 246-276 (ahora: $G S I I)$ ].

5 Carta a Scholem del 22.12.1924. En GB II, p. 508.

6 Asja Lacis. Profession: révolutionnaire. Sur le théâtre prolétarien. Grenoble: Presses Universitaires de Grenoble, 1989, p. 74. 
que este último imprimió en la literatura alemana de los siglos XVIII y XIX. Pero, de este modo, también tocará a sus manifestaciones más recientes en el siglo XX. Señala que su estudio no podría reducirse a una investigación universitaria, sino que se propone establecer "al contrario, una relación directa con los problemas profundamente actuales de la literatura contemporánea" ". Quiere demostrar que la literatura barroca es un "fenómeno análogo al expresionismo, en lo que toca al lenguaje de las formas", ocupándose particularmente del "problema artístico de la alegoría, de los emblemas y del ritual"8. En relación con esto, Asja Lacis destaca la importancia que, en efecto, tienen estos medios expresivos en la poética moderna, por ejemplo en las obras de agitprop de Brecht, pero también en sus dramas (Mahagonny, La importancia de estar de acuerdo), e incluso en Jean Genet y Peter Weiss.

\section{El expresionismo, barroco de los años veinte}

Para el filósofo, el movimiento moderno de las vanguardias europeas expresa la dolorosa condición del lenguaje tras la guerra mundial. En 1915, el teatro expresionista de Franz Werfel se interesaba por los mismos temas (véase sus Troyanas) que en 1625 ocuparon al barroco Martin Opitz, empleando un modo expresivo tan torturado como éste. Una versificación escandida sin cesar por la declamación dramática hace resonar, tanto en uno como en el otro, los lamentos de una época decadente:

Sobre todo en lo lingüístico es donde salta a la vista la analogía entre los esfuerzos de entonces con los del pasado más reciente, e incluso con los actuales. Peculiar de unos y otros es sin duda la exageración. Las obras de estas dos literaturas no han nacido tanto de una existencia común como del hecho de que del modo más violento tratan de disimular el déficit de productos válidos en el terreno de las letras. Pues, de igual modo que en el expresionismo, la del Barroco es sin duda una época no tanto de práctica artística propiamente dicha como de voluntad artística inquebrantable. [...] Y es en esa misma voluntad donde se fundamenta la actualidad del Barroco, tras el derrumbamiento de la cultura clasicista alemana?

Tras la guerra de Treinta Años, así como de la Primera Guerra Mundial, el escritor no puede aspirar al ideal de una obra de arte aislada y cerrada en sí misma, en el sentido de un simbolismo tradicional: el verdadero ejercicio, por decir noble, del arte (romántico o clásico) reside en una "voluntad artística inquebrantable" (barroca o expresionista). Lamentándose por la potencia imaginaria del lenguaje y en busca de un nuevo pathos, el dramaturgo se esfuerza en fabricar arcaísmos, neologismos rústicos, series interminables de versos entrecortados, el "ritmo intermitente de una pausa constante, de un repentino

Id.

Id.

El origen del Trauerspiel alemán. En Obras I.1, p. 255 [GS I, p. 235]. 
cambiar de dirección para petrificarse nuevamente" ${ }^{10}$. Prefigurando el expresionismo, el barroco se vuelve pesado en su despliegue material: jamás hubo poesía menos aérea. $\mathrm{Su}$ pesadez refleja, a fin de cuentas, un mundo sin gracia:

[...] el Trauerspiel alemán se sume por entero en el desconsuelo de la condición terrena. Si reconoce una redención, ésta se encuentra más en lo profundo de dicha fatalidad que en la idea de consumación de un plan divino de la salvación. El alejamiento de la escatología por parte del teatro religioso caracteriza el nuevo drama en toda Europa $[\ldots]^{11}$.

Esta renuncia rabiosa a toda posibilidad de redención en una obra serena y soberana repercute hasta en las vanguardias europeas más o menos revolucionarias de los años 1920. Pero en el siglo XVII, encuentra su contraparte en una política conservadora:

Pues a este [el barroco] la idea de catástrofe se le antoja cabalmente antitética del ideal histórico de la restauración. Y sobre esta antítesis se acuña la teoría del estado de excepción ${ }^{12}$.

Y es aquí donde se bifurcan los caminos del barroco y de las vanguardias. Al querer evitar el sangriento estado de excepción de los imperios orientales, pero consumar el de un tirano iluminado en Europa, los autores del Trauerspiel (especialmente Opitz, Gryphius y Lohenstein) buscan con todas sus fuerzas, aconsejando al príncipe, estabilizar el poder absolutista. Por el contrario, los escritores modernos son indiferentes al Estado, llegando incluso a oponerse a él para poder desbancarlo.

\section{El Trauerspiel, género dialéctico}

Además de esta actualidad diferenciada del Trauerspiel en relación con la vanguardia y, a modo general, en toda forma de literatura preocupada de su propia época, Benjamin no desconoce la intención didáctica de estas obras edificantes del siglo XVII que, interpretadas por estudiantes para estudiantes, permitirían ganar a los jóvenes para la religión. Podemos imaginar que en 1916, año de concepción de este libro, este objetivo afectó al militante que deseaba introducir a los estudiantes en una nueva religiosidad del presente. Los artículos que datan de esta época ponen de relieve, en sus momentos musicales, el aspecto redentor del barroco alemán -posición que luego será matizada. Por lo demás, Benjamin intuye en el furor enunciativo del Trauerspiel, la nostalgia de un lenguaje divino y reconciliado, y cita a este respecto sus propios textos sobre el lenguaje y la traducción. Trabajar sobre el Trauerspiel significaba quizás reformular el problema de la lengua pura y de la educación de la juventud en el contexto de una

Ibíd., p. 418 [GS I, p. 373].

Ibíd., p. 285 [GS I, p. 260].

Ibíd., p. 269 [GS I, p. 246]. 
época decadente. En otras palabras, se trata de poner en práctica una arqueología de la modernidad.

Con su tesis de habilitación, Benjamin desea también demostrarle a los universitarios, mediante una comparación sistemática con la tragedia, que el drama barroco alemán constituye un género en sí mismo, y no una pálida imitación de las grandes obras clásicas. Si el desdichado candidato logrará (en retrospectiva) revalorizar este género entre los especialistas de la literatura alemana, la cualidad pétrea de estas obras hace que este teatro sea todavía hoy desconocido por el público masivo. En este sentido, la expresión "drama barroco" puede inducir a error, en tanto evoca un teatro católico que contiene ciertas dosis de comedia, como es el caso de Calderón o de Shakespeare. No obstante, el Trauerspiel es esencialmente un género triste: la asociación de los términos Trauer (tristeza o duelo) y Spiel (juego) significa literalmente "juego de duelo" o, incluso "obra triste". El lugar de nacimiento del Trauerspiel no es ni español ni británico, sino una región protestante que fuera anexada por la monarquía austríaca: Silesia (que hoy es parte de Polonia). En fin, este género particular no se caracteriza por sus aspectos lúdicos (como La vida es sueño), sino más bien por un espíritu riguroso de inspiración luterana y orientación política. Es Martin Opitz (1587-1639), un poeta calvinista, quien teoriza las reglas literarias de este teatro para dejar atrás el proselitismo de los dramas de los mártires jesuitas. Sus propias obras reinterpretan la situación de los protestantes en un contexto griego: ponen en escena a heroínas paganas (Judith, Antígona) que, víctimas de una opresión política y religiosa, llaman a la rebelión. También simbolizan, en una época en que Sajonia había cedido Silesia a los Habsburgos, esta región que el tirano católico somete a la opresión como método de conversión. Heredero de Opitz, el luterano Andreas Gryphius (1616-1664) proclama una resistencia pasiva: en el drama Papinianus, el legista magnánimo rechaza encubrir el fratricidio demente del que el rey Caracalla se ha declarado culpable. Permanece fiel al monarca y rechaza darse a la fuga o rebelarse ante su cólera homicida: para Papinianus (que parece encarnar las posturas de Gryphius), Dios ha escogido este absolutismo inestable para los hombres, y el hombre devoto debe asumir la tarea política que le ha sido encomendada. Menos ortodoxos, Daniel Casper von Lohenstein (1635-1683), Johann Christian Hallman (1640-1716?) y August Adolph von Haugwitz (1647-1706) hacen de sus propios héroes (Ibrahim Bassa, Epicharis, Ibrahim Sultan, María Estuardo, Mariamne...) los modelos de una resistencia más activa. Clásico con Gryphius, barroco con Lohenstein y musical con Hallman (que monta óperas), y nuevamente clásico con Haugwitz (estando todas estas tendencias ya contenidas en Opitz), el Trauerspiel se concentra en el funesto relato de la muerte, a menudo horrible, de un héroe fiel a su fe no obstante la tiranía insensata del poder terrenal. Ritmado por largos monólogos en forma de lamentos y de giros teatrales tan didácticos como artificiales, el Trauerpsiel expresa en sus inicios, que coinciden con la guerra de Treinta Años (1618-1648), el punto de vista de los protestantes que sufren los efectos de las ambiciones políticas de los Habsburgos aliados con la Iglesia Católica Romana. Hacia fines de los años 1660, toda esperanza de independencia por parte de Silesia desaparece. Lohenstein y Hallman abandonan su crítica política para someterse incondicionalmente a la Casa de Austria, y el mismo Hallman se convierte al catolicismo (Haugwitz nunca fue protestante). Pero a pesar de estas conversiones, 
el sentido general del Trauerspiel sigue siendo, para Benjamin, político y religioso. Sus numerosas alegorías (de la Justicia, de la Verdad, etc.) testimonian las vanidades del mundo terrenal y la miserable condición del hombre privado de trascendencia. Epígono decepcionado del milenarismo praguense, el barroco alemán hace el duelo de Dios y de su reino, cuya consumación en la Tierra parece imposible. De ahí que sus autores prefieran, con todo el riesgo que ello implica, plegarse al orden establecido. Pero en la tristeza de las obras de Opitz, Gryphius, Lohenstein, Hallman y Haugwitz, así como en los procedimientos formales que allí operan, reside una profunda verdad que el crítico literario debe exhumar:

El poderoso esbozo de esta forma ha de ser pensado hasta su fin, y solo bajo esta condición puede tratarse la idea del Trauerspiel alemán. Como en las ruinas de los grandes edificios la idea que corresponde a su proyecto habla de manera más impresionante que en otros menores aunque todavía bien conservados, el Tauerspiel alemán propio del Barroco aspira a una interpretación ${ }^{13}$.

Esta potencialización del barroco alemán depende particularmente de un tratamiento dialéctico de su forma expresiva privilegiada, que funda la singularidad de su origen:

Solo el conocimiento filosófico de la alegoría, el conocimiento dialéctico de su forma límite en particular, constituye el fondo sobre el cual con vivos $-\mathrm{y}$, si es que así se puede expresar, hermosos- colores se destaca la imagen del Trauerspiel, que es el único que no lleva adherido el gris de los retoques ${ }^{14}$.

Llevar el Trauerspiel a término implica, pues, reconstituir su forma ideal, el edificio de su pensamiento, tratando su "origen" desde un punto de vista dialéctico.

\section{El origen de un género}

En su prefacio epistemocrítico al Origen del drama barroco alemán, Benjamin afirma querer desarrollar una "ciencia del origen"15. Esta ciencia inaudita ya no consiste, como sucedía con Goethe o Hölderlin, en quebrar la totalidad alcanzada por la obra para liberar una verdad oculta: destrozado por las violencias de su época, el Trauerspiel no pudo encontrar una forma ideal que fracturar.

En efecto, aquel drama se formó -precisamente por haber surgido de modo necesario de esa época suya- gracias a un esfuerzo sumamente violento, lo que ya por sí solo indicaría que no hubo ningún genio soberano que le diera su impronta a aquella forma. Y, sin embargo, es en ella donde se halla el centro de gravedad

$13 \quad$ Ibíd., p. 459 [GS I, p. 409].

14 Ídem.

$15 \quad$ Ibíd., p. 244 [GS I, p. 227]. 
de cada ejemplo del Trauerspiel barroco. Lo que ahí pudo captar cada escritor se encuentra de manera incomparable en deuda con ella, siendo una forma cuya profundidad no se ve perjudicada por la limitación de esos autores ${ }^{16}$.

Parece ser que la operación crítica, hasta ahora tan cara a Benamin, debe invertirse: ya no se trata de recorrer el relieve de un admirable paisaje para identificar algunos accidentes en su geografía, sino de partir desde un sitio desolado para revelar su ideal arquitectónico. En ambos casos, el crítico debe perfeccionar la obra. Pero en el caso del Trauerspiel, ésta se encuentra ya en estado de ruina. No había genio romántico o clásico alguno que pudiera dotar al barroco alemán de una forma finita; cada obra, cada torpe ensamblaje de versos quebrados figuraba los restos de un mundo desencantado. A partir de estos escombros, Benjamin se propone circunscribir el centro invisible.

\section{La dialéctica, testimonio del origen}

La regla de la contemplación filosófica del origen del Trauerspiel no reside en el origen pensado en un sentido puramente lógico -subraya Benjamin, apuntando a Hermann Cohen y, por añadidura, a todo el neokantismo--, sino abordado en términos dialécticos: el origen también remite a un desarrollo histórico. Pero aun cuando se despliegue en la historia, sigue siendo fundamentalmente idealista:

El hegeliano "Tanto peor para los hechos" es sobradamente conocido. En el fondo, lo que quiere decir es: la intelección de las conexiones esenciales le incumbe al filósofo, y las conexiones esenciales siguen siendo lo que son por más que en el mundo de los hechos no se plasmen puramente ${ }^{17}$.

Benjamin parece aquí tomar partido por Hegel: la verdad del barroco (su origen) se encuentra más allá de los hechos, y es en este más allá que el investigador debe encontrar las ideas inmutables. La "idea" de la forma del barroco alemán, señala, es algo que trasciende a cualquiera de sus obras. Benjamin compara esta metaforma, mucho más rica que sus manifestaciones concretas, con las que se hallan en el cielo de las ideas de Platón (sigue refiriéndose al Banquete), reservorio de verdades eternas que se manifiestan en el mundo real, pero también en la monadología de Leibniz o, incluso, en la dialéctica de Hegel. Es en una esfera no empírica, sino metafísica, que debe reencontrarse esta sustancia que origina el género:

Porque, en efecto, el origen no designa el devenir de lo nacido, sino lo que les nace al pasar y al devenir. El origen radica en el flujo del devenir como torbellino, engullendo en su rítmica el material que está en trance de aparecer ${ }^{18}$. 
El Trauerspiel aparece en reacción a su época (siendo su producto necesario), pero no es allí donde encuentra realmente su "origen", en el sentido que Benjamin quiere dar a este término. La potencia de su forma proviene de una esencia constitutiva que ninguna obra manifiesta íntegramente, y que tampoco la historia podría agotar. En su pureza -como la mónada de Leibniz o la posición hegeliana, el mundo en miniatura-, el origen del Trauerspiel se mantiene, quizás más que el origen de lo cómico o de lo trágico, a distancia del mundo empírico. No obstante, surge con esfuerzos renovados en cada obra, fragmentariamente. Sería Trauerspiel una obra que, en uno u otro momento de su desarrollo, permanece fiel a un ideal del Trauerspiel. El barroco alemán nace de una confrontación entre una idea divina y el mundo terrenal, que solo los períodos que la preceden y que la siguen pueden atestiguar:

En cada fenómeno de origen se determina la figura bajo la cual una idea no deja de enfrentarse al mundo histórico hasta que alcanza su plenitud en la totalidad de su historia. El origen, por tanto, no se pone de relieve en el dato fáctico, sino que concierne a su prehistoria y posthistoria ${ }^{19}$.

Pero esta visión idealista no satisface a Benjamin, quien se encarga de señalar sus peligros. Apenas ha citado a Hegel, condena su idealismo exagerado: la certeza de la especulación proviene de que ésta renuncie al "núcleo de la idea de origen" ${ }^{20}$. Benjamin retoma aquí su crítica de los románticos, que hacían desaparecer el contenido (el núcleo duro del origen) en el análisis estético de la forma (el juego de las reflexiones). Para criticar la teleología hegeliana, hace notar que no es posible "como momento constitutivo de la esencia [...] adoptar cualquier "hecho" primitivo sin más"21, y condena la pretensión de un sistema, prefiriendo en su lugar el "mosaico"22. Vuelve a denunciar la violencia formal hegeliana ("Tanto peor para los hechos") desde el punto de vista goethiano ("es monstruoso"): aun cuando se le asemeje, su concepto de origen no se reduce al de idea, ya sea hegeliana o platónica, sino que induce la noción goethiana de fenómeno originario (que ya le había permitido limitar el énfasis de los románticos y que ya contenía la pre y posthistoria de la planta bajo la forma de las raíces y las hojas). Más que enfrentarse a un fenómeno primario desde el punto de vista de su despliegue especulativo, se trata en primera instancia y ante todo de sumergirse en su "más íntima estructura" para, desde allí, revelar el origen, es decir, la copresencia de una positividad terrenal y una negatividad aérea en la fuente del fenómeno mismo.

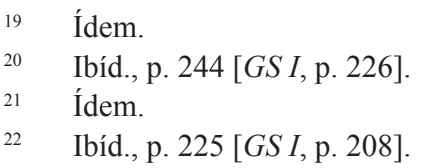




\section{El origen como fenómeno originario}

Comprender el origen del barroco no consistiría en anticiparse a su idea plenamente desplegada, sino en aprehender "la metafísica, [... ] concretamente y en su plenitud, de dicha forma" ${ }^{23}$. Situado en la posthistoria, el crítico no puede reconstruir la confrontación originaria sino a posteriori, partiendo siempre de los fenómenos empíricos, es decir, analizando palabra a palabra distintos pasajes extraídos de distintas obras. No puede poseer la verdad del género como si fuese un saber:

La verdad, representada en la danza de las ideas expuestas, escapa a cualquier clase de proyección en el ámbito del conocimiento. Pero el conocimiento es un haber ${ }^{24}$.

La verdad es la unidad del ser, no del conocer. No puede adquirirse como se obtiene una definición. Ella no permite aproximación o dominio alguno. Tratar de descubrirla, de correr su velo, implicaría hacerla desaparecer. Por lo tanto, es necesario adivinarla bajo su velo, es decir en medio de un enjambre de fragmentos - un centro, esta vez, invisible y no encarnado en un personaje, como era el caso en Dostoievski. En palabras que rememoran la imagen de la obra como hoguera y la dialéctica entre contenido objetivo y contenido de verdad propuesta en el ensayo sobre Las afinidades electivas, Benjamin señala que el origen se manifiesta no por un develamiento, sino por un "llamear del velo", una "combustión de la obra" 25 : al alcanzar su grado más alto de luminosidad, el contenido manifiesto permite adivinar el contenido latente. El orificio en el origen del que surge la idea en la historia marca el lugar incendiado del que irradia la obra en su totalidad: Benjamin no puede sino girar en torno a él, premunido de fenómenos empíricos que se asemejan a los escudos sobre los que la verdad se refleja fragmentariamente. El origen del Trauerspiel no se deduce, pues, de las obras particulares ni de una clasificación a partir de géneros, sino que se discierne en el círculo que estos fragmentos de materia (los pasajes de las obras teatrales) componen en torno a él (el origen), como en torno a un agujero negro. En estricto rigor, el origen no se adivina, sino que se reconoce como lo auténtico que golpea al crítico:

Lo auténtico -ese sello del origen presente en los fenómenos- es objeto de descubrimiento, y de un descubrimiento vinculado de modo único con el reconocimiento ${ }^{26}$.

Este sería el programa -en efecto, bastante poco académico- que se anuncia al comienzo del Origen del drama barroco alemán. En primer lugar, el crítico debe sumergirse en el mundo empírico del género que lo ocupa (el de los versos rotos, el de las obras inconclusas). Desde allí, guiado por una ciencia que emplea no para develar la verdad,

Ibíd., p. 246 [GS I, p. 228].

Ibíd., p. 225 [GS I, p. 211].

Ibíd., p. 227 [GS I, p. 212].

Ibíd., p. 244 [GS I, p. 227]. 
sino para presentarla en su misterio y sin contaminarla con sus propias intenciones, debe revelar el ideal metafísico de dicho género. Finalmente, y llevando a plena conciencia el potencial que hay en él depositado, el crítico contribuye a la restitución de lo que ha sido roto. De este modo, a partir de una ciencia del origen, el crítico puede resucitar el paraíso perdido.

En el cuerpo del texto, Benjamin ejecuta este programa considerando el origen del barroco alemán por oposición a dos géneros ampliamente reconocidos: la tragedia y lo romántico. En la primera parte, titulada "Trauerspiel y tragedia", distingue el origen del Trauerspiel del origen de la tragedia, desde el punto de vista del contenido (el argumento); en la segunda parte, llamada "Trauerspiel y alegoría", lo diferencia del origen del romanticismo, desde el punto de vista de la crítica literaria (las figuras del estilo).

\section{El origen de la tragedia}

Para Benjamin, la tragedia accede más o menos directamente al momento originario en su carácter más demónico: ella se sumerge en la prehistoria de la humanidad, allí donde el hombre comienza a batirse con los monstruos míticos para entrar en la historia. El sacrificio del héroe trágico da inicio a la victoria de los dioses venideros y de los hombres nuevos sobre los dioses antiguos. El espacio de enfrentamiento entre los hombres y los dioses anuncia la liberación de la palabra respecto del derecho escrito, la victoria de la violencia muda de los dioses caprichosos y de las tribus sin ley:

Para el derecho ateniense lo importante y más característico es sin duda el salto dionisíaco, es decir, el hecho de que la palabra ebria, extática, pudiera transgredir el perímetro regular del agón, y que de la fuerza persuasiva del discurso vivo surgiera una justicia mucho más elevada que la que surge del proceso de los clanes contendiendo con armas o con formas verbales obligatorias y codificadas. El logos transgrede en consecuencia la ordalía en dirección a la libertad. Éste es el profundo parentesco entre proceso judicial y tragedia en Atenas. La palabra del héroe, cuando al fin atraviesa esporádicamente la rígida coraza del sí mismo, se convierte sin duda en un grito de indignación ${ }^{27}$.

En la tragedia, explica Benjamin, el hombre está agobiado por el peso del destino, es decir, por el desencadenamiento ciego de los dioses. Pero la potencia trágica proviene de que la asuma completamente: el héroe endosa su culpa, y es a través suyo que balbucean las primeras palabras de la moral. Se libera de esta carga reflexionándola en su propia conciencia y en su lenguaje, precisando si es necesario un sacrificio expiatorio. Tras esto, el error es enmendado ante los espectadores, se crea un nuevo orden, con un Dios 
más justo, que destruye el derecho mítico, triunfa sobre el mundo demónico y libera al hombre de las redes de la naturaleza.

El Trauerspiel desconoce este momento trágico que va de la naturaleza a la historia. Incluso, procede inversamente: parte de la historia de los reyes y de las maquinaciones políticas, y transforma esta historia en naturaleza. Bien querría el tirano -como el mártir- erigir el reino de Dios sobre la tierra. Entonces, reemplazaría el curso errático de las pasiones por una ley moral, como sucede en el estado de excepción. Pero no puede tomar una decisión madurada en su espíritu e iluminada por las voces divinas. Al contrario, gobierna como un animal: siguiendo sus impulsos fluctuantes, se precipita en una locura furiosa (en Papinianus de Gryphius, Caracalla asesina súbitamente a su hermano, sin razón aparente), y luego en una tristeza insondable. Mientras en la tragedia el héroe se emancipa de su condición de creatura de dioses inicuos para inaugurar la era de un derecho más justo y (quizás) de un Dios pacificador, el barroco se resuelve en un destino miserable, carente de toda providencia. Es en este sentido que Benjamin puede leer aquí una secularización: como si la trascendencia duramente ganada por la tragedia se perdiera nuevamente, los cristianos (como Gryphius) son devueltos a un estadio de paganismo que todavía tiene que habérselas con un universo mítico (como Papiniano). Los héroes recaen en una condición humana desesperanzada. En suma, fracasan en el mito.

Mostrando así la profunda diferencia que hay entre Trauerspiel y tragedia, Benjamin implica que la fuente del Trauerspiel no se remonta a la tragedia, entendida como la lucha de los hombres contra los poderes míticos que lo conducen a una nueva era jurídica. El filósofo no devela del todo el origen del Trauerspiel. Todavía debe singularizarlo, y esta vez no desde el punto de vista de la forma argumental, sino de un modo expresivo: mientras que el teatro clásico y romántico emplea el símbolo, el barroco utiliza la alegoría. En el prefacio epistemocrítico, Benjamin desarrolla la idea de que los conceptos (que es necesario construir) elevan los fenómenos (concretos) al nivel de su verdad (metafísica), tal como el contenido objetivo de Las afinidades electivas se elevaba al nivel de su contenido de verdad. En el cuerpo del texto, nos parece que Benjamin aplica esta epistemología, elevando las figuras literarias romántica y barroca del símbolo y la alegoría, al nivel de conceptos que revelan la verdad de los géneros del teatro romántico y del Trauerspiel.

\section{El concepto de símbolo en el Romanticismo}

En Benjamin, el símbolo designa la congruencia inmediata entre significado y significante. En el lenguaje ordinario, se diría que la corona simboliza la monarquía. Pero en el sentido romántico-mesiánico del término, que es el que le interesa al filósofo, significaría más bien que una monarquía divina puede bajar a la tierra. "La medida temporal de la experiencia simbólica es el instante místico"28: gracias al símbolo, la 
naturaleza logra elevarse hacia la luz redentora. Según Benjamin, los románticos dejan escapar esta fuerza teológica del concepto de símbolo -y ya vimos que su formalismo místico consistía en una fuga hacia la reflexión infinita, olvidadiza del origen, de la posición primera y de la materia. En el apéndice a su tesis sobre los románticos, Benjamin criticaba su obsesión con una forma indefinidamente perfectible e incapaz de valorar el contenido ideal del arte. En su tesis de habilitación sobre el barroco, los acusa de reducir el concepto de símbolo a una "penumbra de tonos sentimentales" 29 , y de perder, al mismo tiempo, su contenido sagrado: "la unidad de objeto sensible y suprasensible, la paradoja del símbolo teológico, se distorsiona en una relación entre manifestación e idea" 30 . Sabemos que, para Benjamin, el crítico romántico extravía el contenido en el análisis de la forma. Criticando de este modo su uso sentimental del concepto de símbolo, Benjamin añade que los románticos incluso olvidaban la forma en la estética del contenido. Ambos olvidos, cada uno en un extremo (la forma sin contenido, el contenido sin forma), testimonian para Benjamin la incapacidad de "un temple dialéctico" ${ }^{31}$. Este defecto toca también al autor clásico, cuyo "corazón se pierde en el alma bella" 32 . Clásicos y románticos comparten un concepto inconsistente de símbolo que, lejos de elevar armónicamente lo sensible y lo inteligible en el espíritu, más allá de su fusión originaria, se pierden en extravagantes cursilerías.

Al contrario, la alegoría del drama barroco toma muy en serio el momento simbólico de la palabra. A la inversa del formalismo romántico, "la apoteosis barroca sí es dialéctica", en tanto ella "se consuma en la reversión de los extremos"33. El término alegoría designa habitualmente la personificación de una virtud o de un estadio humano fijado por las convenciones, por ejemplo, la muerte como segadora (con sus atributos: la guadaña, el manto negro, la capucha, e incluso el reloj de arena). Pero Benjamin sostiene que ella no se reduce a esta mecánica vacía y carente de intención:

Y, por otra parte, la alegoría no se encuentra exenta de una correspondiente dialéctica, y la calma contemplativa con que se sumerge en el abismo entre el ser figurativo y el significar no tiene nada de la desinteresada suficiencia que se encuentra en la en apariencia emparentada intención del signo ${ }^{34}$.

A su modo, la alegoría barroca se inscribe en una dialéctica entre naturaleza e historia, entre lo sensible y lo inteligible. Lejos de querer imponer una falsa síntesis, ella designa el abismo que separa el significante del significado: la corona, el cetro y el manto púrpura no remiten a una monarquía de orden divino sino a una ausencia de toda trascendencia en la tierra, en tanto estos atributos evocan una soberanía imperfecta y fragmentaria. Por

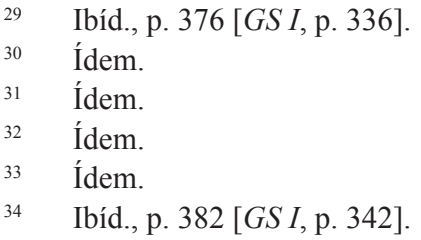


este motivo, y tal como en la Melencolía de Durero, estos accesorios son los objetos de una meditación morosa, la del rey y del cortesano.

Los atributos del soberano no aparecen como símbolos de la historia sino, siguiendo el modo alegórico propio del Trauerspiel, como ruinas de un paisaje devastado y carente de gracia. En el fondo, la alegoría enfrenta el mismo fenómeno que el verdadero símbolo: aquel que supera la alianza sentimental entre el corazón y el alma, pero de acuerdo a una temporalidad distinta. El símbolo consumado deja caer brevemente una luz divina sobre el paisaje que la alegoría presenta como un desierto perpetuo:

Mientras que en el símbolo, con la transfiguración de la caducidad, el rostro transfigurado de la naturaleza se revela fugazmente a la luz de la redención, en la alegoría la facies hippocratica de la historia se ofrece a los ojos del espectador como paisaje primordial petrificado. En todo lo que desde el principio tiene de intempestivo, doloroso y fallido, la historia se plasma sobre un rostro; o mejor, en una calavera ${ }^{35}$.

Mientras que el símbolo ilumina, por un breve instante, una naturaleza repentinamente liberada, la alegoría muestra, por un largo rato -incluso una eternidad-, una historia perpetuamente encadenada. La diferencia entre símbolo y alegoría es ante todo temporal (breve/largo), y esta discordancia de los tiempos genera una distinción en cuanto a sus objetos (naturaleza/historia) y sus perspectivas (redención/catástrofe). La alegoría es un pariente secreto del verdadero símbolo (no el romántico), en el que brilla la esperanza de la salvación. En cierto modo, ella desenmascara el símbolo de pacotilla y todas las falsas reconciliaciones que se le parecen: muestra el rostro hipócrita, mentiroso, de una salvación que carece de dios. De manera más general, la historia a la que se refiere el Trauerspiel remite a una naturaleza entrampada en un proceso histórico de caducidad, que ha sido reducida a un cadáver. Benjamin confirma en Hallman esta alegoría del mundo cruel de la corte:

También Teodorico ha navegado por el mar / en el cual en lugar de las olas el hielo; en lugar de la sal / el secreto veneno, / en lugar de los remos / la espada y el hacha; en lugar de las velas / las telas de araña; / en lugar del ancla / el falso plomo, / rodean el cristal de la barquilla ${ }^{36}$.

En el Trauerspiel, la historia parece estar aun más desencadenada que la naturaleza salvaje: es finalmente esta naturalidad demónica la que triunfa en el mundo histórico. Con sus hallazgos plagados de imágenes, el Trauerspiel parece, a su modo, aproximarse a cierta verdad.

El origen del Trauerspiel no se confunde ni con el del la tragedia (sustraerse a la vida natural), ni con el del Romanticismo (el instante místico de la redención). En

$35 \quad$ Ibíd., p. 383 [GS I, p. 343].

36 Hallman, cit. en Ibíd., p. 419 [GS I, pp. 374-375]. 
comparación con el Clasicismo y el Romanticismo, el drama barroco parece haber quedado en un estadio originario dominado por un demonismo tenebroso: no supo elevarlo al nivel especulativo de una bella y justa verdad que caería desde el cielo sereno de las ideas platónicas en la tierra, sino que oblitera toda trascendencia de su panorama en ruinas. Ciertamente, la negación trabaja su posición, estando el espíritu dominado por los poderes de la materia, pero no parece llegar a una negación completa, menos aun a una resolución espiritual que pondría de manifiesto el conjunto. Allí donde el momento originario parece manifestarse, ya estaría integrado al paisaje natural: las fuerzas del espíritu se petrifican en una historia que ha devenido naturaleza. Lo que Benjamin llama el objeto virtual de su tratado le permitirá acceder a las imágenes de una existencia bienaventurada.

\section{Imágenes barrocas de una existencia bienaventurada}

No obstante la ausencia de toda felicidad en este paisaje en ruinas, Benjamin intenta volver la posición originaria hacia la luz, y encontrar las huellas de una posible redención en este paisaje invadido por el mito. También subraya el momento de la negación, lo que le permite poner en movimiento una dialéctica propiamente barroca. Desde el punto de vista formal, identifica, por ejemplo, en el seno de la alegoría, una dialéctica de la expresión y la convención, de la escritura viva y el código cerrado, cercano al jeroglífico o, incluso, en la profusión de los instrumentos de expiación y de poder, una dialéctica de la dispersión y la recolección. Esta última responde, desde el punto de vista del contenido, a una dialéctica del santo y el tirano, o incluso a la del honor restablecido y del honor burlado. La melancolía misma del Trauerspiel es una dialéctica in nuce. Los autores barrocos heredan una "dialéctica saturnina" ${ }^{37}$ nacida en el pensamiento antiguo, retomada en la Edad Media pero eclipsada por el pensamiento cristiano: dialéctica del genio y de la locura para Aristóteles (es decir, de una intensa actividad y un abatimiento extremo), de los hombres de la tierra y de los del cielo para un contemporáneo de Dante (es decir, de los campesinos y los religiosos), pero también, de manera más general, de la tristeza más severa a la felicidad más beata. La antinomia dominante es de hecho, quizás, esta última: la de la esperanza y la desesperanza, radicalizada en el contraste entre la bufonada y la tristeza. Benjamin subraya ciertos pasajes que, en los Trauerspiele, ponen en escena las payasadas del intrigante que contrastan con la gravedad del rey, y que oponen la "inconfundible mueca del diablo" con la "falsa santidad" 38 del soberano desdichado. Con todo, Benjamin señala en uno de los extraños pasajes del texto en el que el término origen (cuya visión dialéctica da cuenta de las antinomias -sístole y diástole- presentes en ella) bien puede hacer eco del concepto del prefacio: 
La broma más cruel es tan originaria como la diversión más inocua; originariamente las dos están muy próximas, y justamente a la figura del intrigante le debe el Trauerspiel, que a menudo camina sobre zancos, mantener el contacto con el suelo nutricio de experiencias increíblemente profundas ${ }^{39}$.

Las burlas del bufón -que parece ser el único que realmente comprende lo que sucededesmontan al soberano de su pedestal, haciéndolo tocar el suelo nutricio del origen: gracias a él, el Lustspiel (juego alegre) se introduce en el Trauerspiel (juego triste), elevándolo a su forma más acabada mediante una "delicada conexión simbólica"40. Benjamin retoma la expresión de Novalis, cuya dialéctica reflexiva toca esta vez a la verdad que obra en el Trauerspiel. A la posición originaria (la tristeza, la historia hecha mito), el crítico opone una negación (la bufonería, la historia que vuelve a ser historia), elevando así el Trauerspiel hacia la luz del verdadero símbolo (la redención).

De paso, esto hace recordar el profundo interés de Benjamin por el teatro épico de Brecht, que se apoya en la infracción a las reglas y en el histrionismo para crear efectos de distanciamiento. De hecho, la idea original del libro sobre el barroco le sobrevino en 1916 en Génova, durante una representación del Cid en que un pasaje se volvía excesivamente grotesco: la corona torcida sobre la cabeza del rey ${ }^{41}$. Este fallo en la puesta en escena había creado un efecto de distanciamiento avant la lettre: separaba al espectador del destino trágico de los personajes. De este modo, el teatro permitía sustraerse al mito para reflexionar sobre él, tal como hiciera luego Brecht en relación con las mentiras burguesas. En este sentido, hay una "senda de contrabandistas" 42 que va de Gryphius a Brecht y del teatro barroco al teatro épico.

La bufonería produce un efecto de distanciamiento en el Trauerspiel. Y esto, porque el intrigante parece ser el único que advierte lo que está en juego: en realidad, este paisaje no encarna sino una alegoría, es decir, se origina en la subjetividad de quien mira. En cierto modo, el estallido de risa despierta de su sueño a la mirada melancólica, que no percibe en la tierra sino un país devastado. El Trauerspiel parece volver aquí al momento satírico que cierra la tragedia, dándole toda la potencia contestataria de las fuerzas demónicas: "al non linquet del proceso representado solo lo prepara o reacciona el impulso de la comicidad" 43 , escribe Benjamin, es decir, que solo puede poner en obra una negatividad que destruye lo que todavía hay de estático en la posición primera, impulsándola hacia un segundo nivel. La hilaridad demónica devela que la conciencia melancólica no representa sino una "síntesis barata" de la verdadera vida. Benjamin notaba esto en un ensayo sobre el lenguaje (que cita): el mal no comienza con el mundo

\footnotetext{
39 Ídem.

$40 \quad$ Ibíd., p. 339 [GS I, p. 306$].$

41 "Diálogos con Brecht", en Brecht: ensayos y conversaciones. Montevideo: Arca, 1970, p. 110.

42 “Qué es el teatro épico? [2]”. En Obras II.1. Madrid: Abada, 2009, p. 139[GS II, p. 523534].

43 El origen del Trauerspiel alemán. En Obras I.1, p. 327 [GS I, p. 296].
} 
(pues "Dios creó el mundo, y vio que era bueno"), sino con el hombre, en la conciencia del hombre que ha probado el árbol del conocimiento (del mal). El Trauerspiel se abisma en esta proyección antropomórfica que nutre sin fin sus ensoñaciones, pero el diablo se oculta en los detalles de su contemplación alegórica y, mediante la alegría irónica que opone a la tristeza "divina", el espíritu vuelve a dominar los poderes de la materia. La risa de Satanás remite a un conflicto primordial y, al mismo tiempo, rememora la verdadera síntesis, "la que corresponde a la vida" ${ }^{4}$. La oposición entre el bufón y el príncipe imita aquella que se da entre la "espiritualidad absoluta" y la "pura y simple materia", la que se manifiesta históricamente en el conflicto entre lo cristiano y lo pagano, lo olímpico y lo demónico:

La concepción alegórica posee su origen en la confrontación entre la physis cargada de culpa que instituyó el cristianismo y una más pura natura deorum, que se incorporó al Panteón. Al reavivarse lo pagano con el Renacimiento, y lo cristiano con la Contrarreforma, también la alegoría, en cuanto a su forma de confrontación, debió renovarse ${ }^{45}$.

La reflexión de Benjamin sobre la alegoría despliega toda la dialéctica del drama barroco alemán: tanto de dónde proviene -el mundo histórico del que toda trascendencia parece haber desertado, el de las potencias de la materia-, como hacia dónde va -el punto especulativo en el que brilla un espíritu semejante a Dios. Ella interpreta un contexto histórico dado al nivel de un conflicto inmutable, en la esfera de las ideas, entre potencias oscuras y fuerzas luminosas. El abismo que abre la alegoría entre significante y significado, evoca la separación primaria (en la que se hunde la tragedia) entre naturaleza y espíritu, entre lo sensible y lo inteligible, entre lo efímero y lo eterno, y aun más, la posibilidad de su reconciliación.

Así, los momentos cómicos del Trauerspiel permiten sustraerse a la maldición mediante la risa. Pero estos momentos son pocos y, entre los nuevos dramaturgos europeos que renuncian a la escatología, solo el alemán parece siempre perderse en una naturaleza sin gracia:

Pues el drama español -el de más altura de aquel teatro europeo-, en el que los rasgos barrocos se desarrollan de un manera mucho más brillante, con mucho más acierto y más relieve en el seno de un país de cultura católica, resuelve los conflictos de un estado creatural privado de la gracia mediante una reducción, hasta cierto punto lúdica, en el entorno cortesano, de una monarquía que se revela como poder de salvación secularizado. La stretta del tercer acto, con su inclusión indirecta de la trascendencia por así decir como por medio de un espejo, o de un cristal o un teatro de marionetas, le garantiza al drama calderoniano un desenlace superior 
al de los Trauerspielei alemanes. [...] En ninguna otra parte como en Calderón podría estudiarse por tanto la cabal forma artística del Trauerspiel barroco $[\ldots]^{46}$.

Para Benjamin, el barroco español es más logrado que el drama alemán: mediante sus lúdicas puestas en abismo (por ejemplo, en La vida es sueño), Calderón deja caer una luz divina sobre sus personajes. Su dialéctica parece incluso más lograda, como testimonia la del honor burlado y restablecido:

Así, en el drama español, como en ninguna otra parte, la incomparable dialéctica del concepto de honra pudo presentar de manera superior, de manera incluso reconciliadora, el desamparo de la persona en cuanto criatura. El sangriento suplicio en que concluye la vida de la criatura en el drama de mártires tiene su contrapartida en el calvario de la honra, que, por ofendido que haya sido, puede restablecerse al final del drama calderoniano por un decreto real o un sofisma. Pues el drama español descubrió en la esencia de la honra la espiritualidad de la criatura adecuada a su cuerpo, y con ello un cosmos de lo profano que no se les reveló a los escritores alemanes del Barroco, ni siquiera a los teóricos posteriores ${ }^{47}$.

Igualmente, Calderón logra transformar en santo al cortesano manipulador, calculador e inauténtico. Haciendo que Dios intervenga con poleas en escena, Calderón franquea, al mismo tiempo, la subjetividad de su tristeza:

La subjetividad, que como un ángel se precipita en las profundidades, es recuperada en alegorías y fijada en el cielo, es fijada a Dios, a través del recurso a la "ponderación misteriosa" 48 .

Del mismo modo, la oposición entre felicidad y tristeza no es superada realmente sino en el teatro español, y esto gracias a un movimiento dialéctico de resolución de las tensiones.

Pero Benjamin advierte lo mismo en el teatro inglés. Identifica en Shakespeare una bufonería (véase Iago, Polonius, Rosencrantz y Guildenstern) y un juego lúdico en el trayecto del héroe (Hamlet) que arrancan al espectador de su melancolía en un estallido de risa, o lo transportan súbitamente hacia una luz redentora. Hamlet encarna este tipo de retorno:

Su vida, en cuanto objeto que se ofrece a su luto de modo ejemplar, remite, previamente a la extinción, a la providencia cristiana, en cuyo seno la tristeza de sus imágenes se transforma en existencia bienaventurada ${ }^{49}$.

Ibíd., p. 392 [GS I, p. 266]

$48 \quad$ Ibíd., p. 459 [GS I, p. 409].

49 
La chispa aparentemente cristiana que surge de la rigidez barroca del melancólico no es, en estricto rigor, ni estoica ni cristiana: es ante todo el fulgor (quizás judaico) de un combate emancipador y de una confrontación dialéctica.

En todo caso, Benjamin considera que el barroco inglés y español (especialmente este último) están mejor logrados que el barroco alemán. El Trauerspiel más acabado sería aquel que, como Calderón, transforma el desarrollo de la acción en una totalidad alegórica que ha de ser fragmentada, para luego trocar la tristeza en una risa redentora. De la posición originaria a la resolución de las tensiones, el crítico lleva también las contradicciones propias del barroco alemán a su propia superación en el barroco español.

En el fondo, el barroco español y el Trauerspiel alemán responden, cada uno a su manera, al mismo problema: la ausencia de trascendencia en la tierra. En la operación crítica, el teatro de Calderón parece cumplir el mismo rol que la historia de los jóvenes vecinos integrada por Goethe a su novela Las afinidades electivas: mediante su carácter estético cumplido y lúdico, evoca la posibilidad de una redención en el seno de un mundo telúrico, lleno de tristeza. Pero se inserta en el conjunto más amplio del barroco europeo, que incluye también al drama silesio, menos logrado desde el punto de vista estético, pero "más responsable" en cuanto a la ausencia de toda trascendencia. Tal como, en Goethe, la felicidad de los jóvenes vecinos pasa como una estrella fugaz a espaldas de los protagonistas envejecidos por un duro destino, el barroco español atraviesa el cielo melancólico del barroco alemán como un meteoro incandescente. Es por contraste que ambos adquieren su valor, y es este fulgor en las tinieblas el que testimonia un origen circunscrito dialécticamente.

\section{Referencias bibliográficas}

Benjamin, Walter (1970), Brecht: ensayos y conversaciones. Montevido: Arca. (1972-1999), Gesammelte Schriften I-VII. Frankfurt: Suhrkamp. (1995-2000), Gesammelte Briefe I-VII. Frankfurt: Suhrkamp. (2006-2009), Obras I-II. Madrid: Abada. (2008-), Werkeund Nachlass. Kritische Gesamtausgabe I-XXI. Frankfurt: Suhrkamp.

Buci-Glucksmann Christine (1984), La raison baroque. De Baudelaire à Benjamin. Paris: Galilée.

Jobez Romain (2010), Le théâtre baroque allemand et français: le droit dans la littérature. Paris: Garnier.

Lacis, Asja (1989), Profession: révolutionnaire. Sur le théâtreprolétarien. Grenoble: Presses universitaires de Grenoble.

Menke Bettine (1991), Sprachfiguren. Name, Allegorie, Bild nach Benjamin. Munich: Fink.

(2010), Das Trauerspiel-Buch: der Souverän - das Trauerspiel Konstellationen - Ruinen. Bielefeld: Transkript. 
Nägele Rainer (1991), Theater, Theory, Speculation. Walter Benjamin and the Scenes of Modernity. Baltimore: John Hopkins University Press.

Pinotti Andrea (dir.) (2003), Giochi per melanconici. Sull' Origine del dramma barocco tedesco di Walter Benjamin. Milan: Mimesis.

Reijen Willem Van et Herman Van Doorn (ed.) (1992), Allegorie und Melancholie. Francfort: Suhrkamp.

Sagnol Marc (2003), Tragique et tristesse. Walter Benjamin, archéologue de la modernité. Paris: Cerf.

Steiner Uwe (1989), "Allegorie und Allergie. Bemerkungen zur Diskussion um Benjamins Trauerspielbuch in der Barockforschung", en Daphnis 18, p. 641701.

(1992), "Säkularisierung. Überlegungen zum Ursprung und zu einigen Implikationen des Begriffs bei Benjamin", en Walter Benjamin 1892-1940. Zum 100. Geburtstag, Bern/Berlin, Peter Lang, pp. 139-187.

Urbich Jan (2012), Darstellung bei Walter Benjamin: die "Erkenntniskritische Vorrede" im Kontext ästhetischer Darstellungstheorien der Moderne. Berlin: De Gruyter.

Weber Samuel (2004), Theatricality as Medium. New York: Fordham University Press, p. 160-180.

Weidner Daniel (ed.) (2010), Profanes Leben. Walter Benjamin Dialektik der Säkularisierung. Francfort: Suhrkamp. 